\title{
Compensation and the Corporate Employee Benefits: Exploring The Dimensions of Employer Brand Practices in The Information Technology Firms in India
}

\author{
Dr. Naga Krishna. Pusuluri \\ Associate Professor, MBA Dept. St.Martin's Institute of Business Management, Dhulapally, Secunderabad-014
}

\begin{abstract}
Employee compensation is the heart of the employment relationship, being of importance to both employees and employers. In India attracting, engaging and talent retention are not only involving questions of compensations packages. Employment experience in India also consists of economic, social, psychological, motivational and religious aspects. Current employees are the first brand ambassadors. Attracting and retaining high performing employees is a huge challenge for international companies. The compensation system of the Organization shows effect on employer branding and its try to retain talent employees for the long term success of the organization and value proposition of the organization.
\end{abstract}

Keywords: compensation system, employer branding, retain talent, value proposition.

\section{Introduction}

Ambler and Barrow (1960) have defined employer branding as the development and communication of an organization's culture as an employer in the market place. Minchington defines employer brand as "the image of organization as a great place to work in the mind of current employees and key stakeholders in the external market (active and passive candidates, clients, customers and other key stakeholders). The art and science of employer branding is concerned with the attraction, engagement and retention initiatives targeted at enhancing company's employer brand. Employer branding is central to the concept in HR Marketing. It defines the personality of a company as a preferred employer. Since replacing skilled employees can be problematic, managers will be able to apply the variables in reducing the high rate of employee turnover. This situation demands that management should identify the reason/s for this frequent change of employment by employees. Once this reason/s has been identified, management can then device retention strategies that will help in keeping essential employees for a rather longer tenure. While functional turnover can help reduce suboptimal organizational performance, high turnover can be detrimental to the organization's productivity. This can result in the loss of business patronage and relationships, and can even jeopardize the realization of organizational goals. Turnover is not only destructive to organizations, it is also costly. Every time an employee quits, a replacement must be recruited, selected, trained and permitted time on the job to gain experience. Apart from the costs that are directly associated with recruiting and training a new employee, other indirect costs exist. The organizations lost productivity, social capital and suffer customer defection when a productive employee quits. Knowledge, skills and contacts that a departing employee takes out of the Organization constitutes a huge loss. These attributes are, in most cases, lost to a competitor organization that may use this to gain competitive advantage.

\section{Review of Literature}

Recently the term has evolved to include a wide set of company activities aimed at recruiting and retaining talented professionals (Mosley, 2007 and Davies, 2008). In this expanded sense, the term "employer branding" encompasses the process of building the employer brand and differentiating it to make it competitive, as well as the specific actions undertaken to attract, recruit, select, retain, recycle and release employees (Sutherland et al., 2002). Throughout the varied processes and activities collectively referred to as "employer branding", employee commitment to the employer brand is a key indicator of the state of the relationship between the employee and the employer (Kimpakorn and Tocquer, 2009 and Fernandez-Lores, 2012).

The American Marketing Association defined brand as a name, term, sign, symbol, or design, or combination of them, intended to identify the goods and services of one seller or group of sellers and to differentiate them from those of competitors (Schneider, 2003).The term branding when applied to the employer suggests the differentiation of a firms' characteristics as an employer from those of its competitors. It highlights the unique aspects of the firms' employment situations (Ambler and Barrow, 1996). It includes the firms' value system, policies and behaviours towards attracting, motivating and retaining current and potential employees. EB has been described in three- step process by human resource practitioners through valuation approach (Sullivan, 2002; Eisenberg et al. 2001. The understanding of factors contributing towards employer 
attractiveness is essential for employer branding valuation. At certain places in this study the term "employer branding" and "employer attractiveness" has been interchangeably used.

Although employer branding is still a relatively young field, several models can already be found in the literature (Backhaus and Tikoo, 2004, Mosley, 2007 and King and Grace, 2010). Some researchers consider employer branding strategies to be a source of sustainable competitive advantage (Kimpakorn and Tocquer, 2009, Maxwell and Knox, 2009 and Edwards, 2010), making the concept analogous to that of consumer branding (Keller and Lehmann, 2006). This group of researchers holds that employer branding is multidisciplinary, and that its aims are, externally, to make sure that the employer brand attracts talent (Miles and Mangold, 2004, Barrow and Mosley, 2005 and Gavilan and Avello, 2011) and, internally, to ensure that this talent commits itself to the company (Burmann et al., 2009 and Fernandez-Lores, 2012).

\section{Research Methodology}

The present study is comparative in nature. The study is trying to explore the practices of employer branding, factors influencing the adoption of the same, impact compensation and benefits of the employee on the employee retention of the firm, benefits of employer brand practices among the IBM and Hexaware is studied as comparative basis.

\subsection{Objectives of the Study}

1. To examine the Compensation and benefit strategies adopted by the sample IT firms to build their employer branding in the IT sector.

2. To study the impact of Reward and Recognition on the retention of the employees among the sample units.

3. To identify the benefits of employer branding observed in IBM and Hexaware companies.

\subsection{Hypotheses}

H1: There is significant difference between IBM and Hexaware respondents with regard to Benefits of employer brand practices in IT sector in India.

H2: There is significant difference between the mean ranks of the perceptions of the employees in the sample with regard to Compensation as a factor in the employer brand development practice in IT sector.

H3: There is significant difference between the mean ranks of the perceptions of the employees in the sample with regard to rewards and recognition as a factor in the employer brand development practice in IT sector.

\subsection{Sampling Design}

The primary data are collected through survey method. Survey is conducted using well formulated questionnaire. Quota sampling method with Simple random selection of respondents is applied for generating data. Samples for the purpose of the study are selected systematically. Totally 616 questionnaires are distributed among the total employees of HEXAWARE and IBM in Chennai who are around 8,000. Out of the distributed questionnaires, 116 are not usable. Only 500 of them are found suitable for primary data analysis. Hence the exact sample size is 500. The quota sampling technique is adopted to collect the data from IBM and Hexaware. Equal importance is given to both the companies in the sample. 250 samples from IBM and another 250 samples from Hexaware are used for analysis.

\subsection{Questionnaire Design}

The primary data are collected through questionnaire survey. The respondents are asked to give their opinion relating to employer branding. The first part of the questionnaire comprises personal and organizational details with optional questions. The second part includes statements relating to the six elements (variables) namely compensation and benefits, work environment, career development, reward and recognition, organisational commitment, communication and leadership style with Likert's 5 point scale.

\subsection{Scaling Technique in the Questionnaire}

The questionnaire comprises of both optional type and Statements in Likert's 5 point scale. The responses of these sections are obtained from the employees of HEXAWARE and IBM companies in the 5 point scale, which ranges as follows:

$\begin{array}{ll}\text { Strongly agree } & 5 \\ \text { Agree } & 4 \\ \text { Neutral } & 3 \\ \text { Disagree } & 2 \\ \text { Strongly Disagree } & 1\end{array}$




\section{Data Analysis And Results Discussion:}

The primary data collected are analyzed by using Statistical Package for Social Sciences (SPSS) version 15 of computer packages. The study is conducted in two parts. In part-I, the data is classified on the basis of the profile the employees and the profile of the firm using descriptive statistical tolls like, percentage analysis and weighted average technique. The second part is dealing with the establishing the compare and contrast between the IBM and Hexaware with regard to employer brand practices adoption, practice and review from time to time. On the basis of nature of data both parametric and non parametric statistical tests are administered on the data.

\subsection{Descriptive Analysis}

Distribution of sample on the basis of standard of compensation and benefits

\begin{tabular}{|l|l|l|l|l|}
\hline \multirow{2}{*}{ Standard of Compensation and Benefits } & IBM & Hexaware \\
\cline { 2 - 5 } & Frequency-(N) & Percentage-(\%) & Frequency-(N) & Percentage-(\%) \\
\hline Custom designed standard & 55 & 22.00 & 145 & 58.00 \\
\hline Industry standard & 97 & 38.80 & 53 & 21.20 \\
\hline International standard & 98 & 39.20 & 52 & 20.80 \\
\hline Total & 250 & 100.00 & 250 & 100.00 \\
\hline
\end{tabular}

Source: Primary data/ Structured Questionnaire

It is noted from the table4.1.1, that IBM follows international standard of compensation and benefits is expressed by 39.20 percent of the employees as against to 20.80 percent in hexaware. IT is followed by 30.80 percent of the employees in IBM feels that, the compensation is at on par with the industry standard and 22 percent of them feel that, the compensation system is custom designed one. In case of hexaware, the compensation system is designed and adopted on the basis of custom designed standard, is expressed by 58 percent of the employees in the sample. Only 20.80 percent is agreed the compensation and benefits are paid as on par with the international standard. Hence, there is a long way to fix the uniform standard in compensation and benefits in both the companies. When comparing both the companies in the sample, it is IBM is better when compared to hexaware. Hence, hexaware, need to focus on compensation system to retain the talent and to improve the employer brand image in the market.

Chart-4.1.1: Distribution of sample on the basis of standard of compensation and benefits

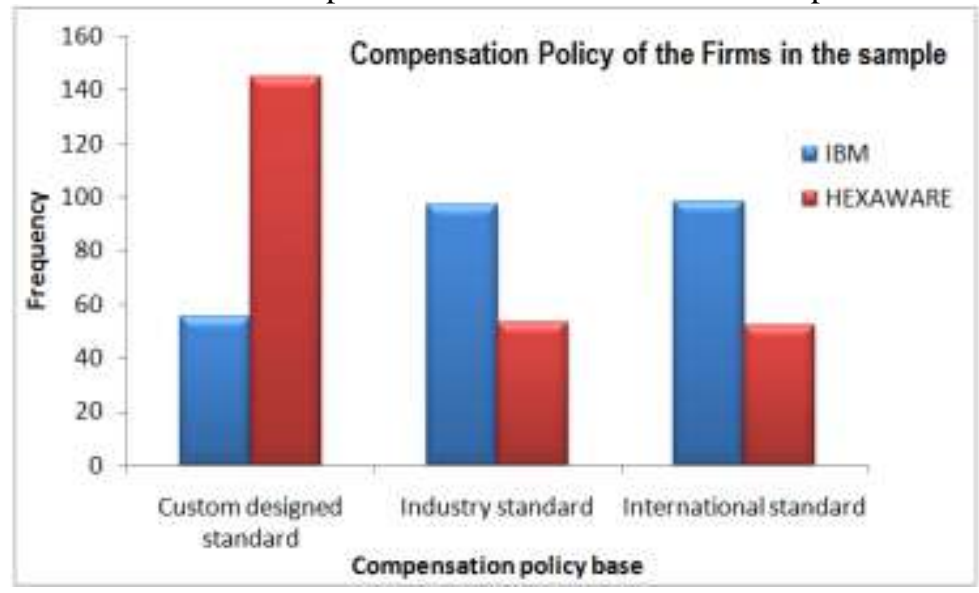

4.1.2 Distribution of sample on the basis of Rewards and Recognition to employees

\begin{tabular}{|l|l|l|l|l|}
\hline \multirow{2}{*}{ Reward and recognitions to employees } & IBM & Hexaware \\
\cline { 2 - 5 } & Frequency-(N) & Percentage-(\%) & Frequency-(N) & Percentage-(\%) \\
\hline Conservative and not comparable & 90 & 36.00 & 99 & 39.60 \\
\hline Fair and attractive & 73 & 29.20 & 95 & 38.00 \\
\hline Best in class and above the range & 87 & 34.80 & 56 & 22.40 \\
\hline Total & 250 & 100.00 & 250 & 100.00 \\
\hline
\end{tabular}

Source: Primary data/ Structured Questionnaire

It is noted from the table 4.1.2, that rewards and recognition related aspects at work is perceived by the employees of IMB are as follows. The employees of IMB feels the rewards given to them are conservative and not comparable by 36 percent, fair and attractive by 29.20 percent and best in class and above the range by 34.80 percent in the sample. On the other hand, it is observed that, 39.60 percent of the employees from hexaware feels that, the rewards given are conservative and not comparable, 38 percent feels that fair and attractive and 22.40 percent views as best in class and above the range. It indicates that IBM is good in reward and recognition of the employees at work for their services. Rewards and recognition is more important to 
improve the morale of the employees at work place. Rewards can help the employees to grow in career and to have good level of loyalty towards the company. The employee loyalty is important in improving the employer brand image in the market place. Hence, IT firms in the sample need to think of preparing the effective and reward system based on transparent performance standards. This can help in improving the trust on the system and management and loyalty towards the company.

Chart-4.1.2: Distribution of sample on the basis of Rewards and Recognition to employees

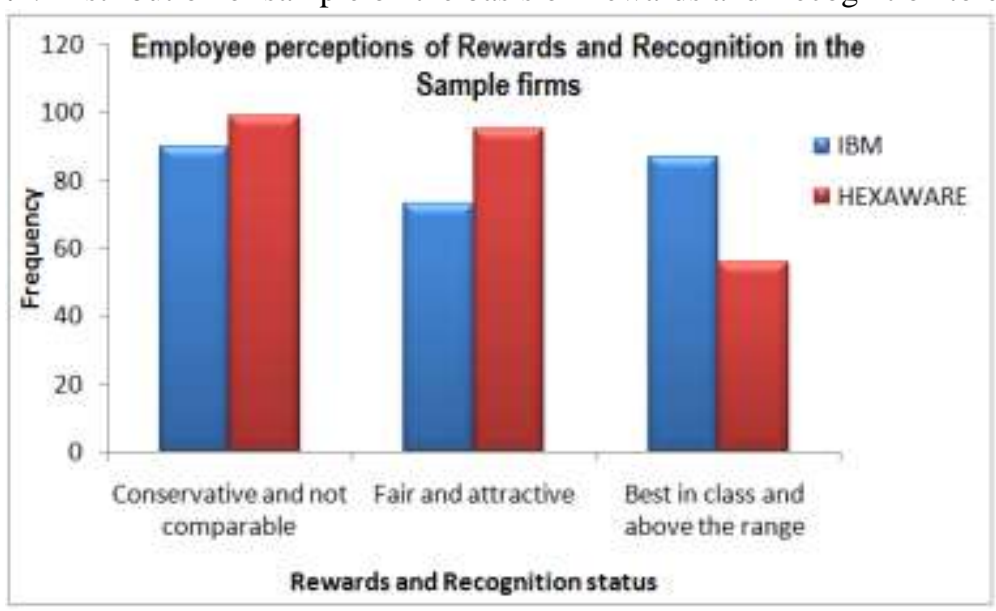

4.1.3: Level of agreement on the employer brand practices in the dimension of Compensation and Benefits

\begin{tabular}{|l|l|l|l|l|l|}
\hline Sl. No. & Compensation and Benefits & \multicolumn{2}{l|}{ IBM } & \multicolumn{2}{l|}{ Hexaware } \\
\cline { 3 - 6 } & & Mean & SD & Mean & SD \\
\hline 1 & Fair and Industry standard pay package & 4.71 & 0.565 & 4.35 & 0.796 \\
\hline 2 & Remuneration for additional work & 4.40 & 0.568 & 4.14 & 0.790 \\
\hline 3 & Performance based reward system & 4.38 & 0.821 & 3.74 & 0.917 \\
\hline 4 & Health, safety and welfare measures & 4.09 & 0.928 & 4.11 & 0.952 \\
\hline 5 & Financial security to self and family in emergencies & 4.01 & 0.996 & 3.94 & 0.978 \\
\hline
\end{tabular}

Source: Primary data/ Structured Questionnaire

It is noted from the table 4.1.3, that the prime variables influencing the compensation and benefits as employer brand practices in IT sector are unanimously agreed by the respondents from both IBM and hexaware with high level of mean values. The primary variables are identified with the higher mean score of above 4.30.The prime variables influencing employer brand image in IT sector are fair and industry standard pay package and remuneration for additional work. The secondary factors are performance based reward system, health safety and welfare measures and financial security to self and the family in emergencies. Hence, a fair remuneration of the work and the rewards for additional work needs to be ensured at all point of time to build the employer brand image among the employees and thereby in the market.

\subsection{4: Level of agreement on the employer brand practices in the dimension of Rewards and Recognition}

\begin{tabular}{|l|l|l|l|l|l|}
\hline Sl. No. & Reward and recognition & \multicolumn{2}{|l|}{ IBM } & Hexaware \\
\cline { 3 - 6 } & & Mean & SD & Mean & SD \\
\hline 1 & Rewards for the professional excellence & $\mathbf{3 . 1 4}$ & 1.393 & $\mathbf{3 . 0 4}$ & 1.402 \\
\hline 2 & Recognition of talents and encouraging & $\mathbf{3 . 1 2}$ & 1.393 & $\mathbf{3 . 0 2}$ & 1.379 \\
\hline 3 & Supportive for creativity and innovations & $\mathbf{3 . 0 9}$ & 1.387 & 2.96 & 1.387 \\
\hline 4 & Research and development opportunities at work & $\mathbf{3 . 0 8}$ & 1.387 & 2.95 & 1.376 \\
\hline 5 & Patenting and ownership of knowledge & $\mathbf{3 . 0 6}$ & 1.371 & 2.85 & 1.401 \\
\hline
\end{tabular}

Source: Primary data/ Structured Questionnaire

It is found from the table 4.1.4, that, the variables in reward and recognition as a factor in employer brand building is observed in the order of priority are Rewards for the professional excellence with the mean value of 3.14 and 3.04, Recognition of talents and encouraging with the mean value of 3.12 and 3.02 , Supportive for creativity and innovations with the mean value of 3.09 and 2.96, Research and development opportunities at work with the mean value of 3.08 and 2.95 and Patenting and ownership of knowledge with the mean value of 3.06 and 2.85 in IBM and Hexaware respectively. Hence, reward and recognition system is also important for the benefit of the improving employer brand in the market. 


\subsection{Data Analysis using Friedman test}

Null Hypothesis: Ho: There is no significant difference between the mean ranks of the perceptions of the employees in the sample with regard to Compensation as a factor in the employer brand development practice in IT sector.

Table-4.2.1: Mean ranks of the employer brand practices in the dimension of Compensation and Benefits along with result of the Friedman test

\begin{tabular}{|l|l|l|l|c|}
\hline Sl. No. & Compensation and Benefits & Mean Rank & Chi square value & P Value \\
\hline 1 & Fair and Industry standard pay package & 8.41 & & \\
\hline 2 & Remuneration for additional work & 7.22 & & \\
\hline 3 & Performance based reward system & 7.95 & $\mathbf{1 2 1 . 2 3 0}$ & $\mathbf{0 . 0 0 0} * *$ \\
\hline 4 & Health, safety and welfare measures & 8.71 & \\
\hline 5 & Financial security to self and family in emergencies & 8.68 & & \\
\hline
\end{tabular}

Source: Primary data/ Structured Questionnaire

Since $\mathrm{p}$ value is less than 0.01 , the null hypothesis, There is no significant difference between the perceptions of the employees in the sample with regard to Compensation as a factor in the employer brand development practice in IT sector is rejected at $1 \%$ level of significance. Hence, it is concluded that, there is a highly significant difference between the perceptions of the employees in the sample with regard to Compensation as a factor in the employer brand development practice in IT sector. Based on the mean value, it is noted that, health, safety and welfare measures and financial protection to self and family are the two major variables act as a prime in compensation factor of employer brand practice in It sector. Hence, the It firms in the sample need to focus on these dimensions while framing the compensation policy of a company in order to have a competitive and contemporary compensation policy as a employer brand practice in the market place and to attract the clients and potential employees towards the company.

Null Hypothesis: Ho: There is no significant difference between the mean ranks of the perceptions of the employees in the sample with regard to rewards and recognition as a factor in the employer brand development practice in IT sector.

Table 4.2.2: Mean ranks of the employer brand practices in the dimension of Rewards and Recognitionas a factor in the employer brand development practice in IT sector

\begin{tabular}{|l|l|l|l|l|}
\hline Sl. No. & Reward and recognition & Mean Rank & Chi square value & P Value \\
\hline 1 & Rewards for the professional excellence & 5.31 & & \\
\hline 2 & Recognition of talents and encouraging & $\mathbf{5 . 6 6}$ & & \\
\hline 3 & Supportive for creativity and innovations & 5.21 & $\mathbf{1 2 5 . 6 5 3}$ & $\mathbf{0 . 0 3 2} *$ \\
\hline 4 & Research and development opportunities at work & 5.54 & & \\
\hline 5 & Patenting and ownership of knowledge & $\mathbf{5 . 7 8}$ & & \\
\hline
\end{tabular}

Source: Primary data/ Structured Questionnaire

Since $\mathrm{p}$ value is less than 0.05 , the null hypothesis, There is no significant difference between the perceptions of the employees in the sample with regard to rewards and recognition as a factor in the employer brand development practice in IT sector is rejected at 5\% level of significance. Hence, it is concluded that, there is a significant difference between the perceptions of the employees in the sample with regard to rewards and recognition as a factor in the employer brand development practice in IT sector. Based on the mean ranks, it is noted that, patenting and ownership of knowledge and recognition of talents and encouraging are the two important variables in the reward and recognition factor of employer brand management in the sample firms in IT sector. Hence, rewards and recognition of young talents play a role in employer brand building in the IT sector.

\subsection{Data Analysis using Factor Analysis}

Grouping the variables gives more clarity on the subject and also on the decision mechanism design. In view of this researcher grouped the items in to groups using Principal Component Analysis with Varimax and Kaiser Normalization. In this part of the analysis, the scholar is trying to group the dimension of factors influencing employer brand practices in IT sector as items in the questionnaire into factors. The results of the analysis are presented below.

\section{Factor Analysis-I: Factors influencing employer brand practices in IT sector}

The dimension of Factors influencing employer brand practices in IT sector consist of 15 variables therefore the data reduction is done through the application of factor analysis by principal component method and the following results are obtained 
Table-4.3.1: Showing KMO and Bartlett's Test

\begin{tabular}{|l|l|l|}
\hline \multicolumn{2}{|l|}{ Kaiser-Meyer-Olkin Measure of Sampling Adequacy. } & .743 \\
\hline Bartlett's Test of Sphericity & Approx. Chi-Square & 613.546 \\
\hline & df & 105 \\
\hline & Sig. & .000 \\
\hline
\end{tabular}

Source: Primary data/ Structured Questionnaire

From the above table it is found that KMO measure of sampling adequacy is .743 , Bartlett's test of Sphericity with approximate chi squire value $613.546, \mathrm{P}=.000$ are statistically significant at $1 \%$ level this implies the sample size is adequate to ascertain the Factors influencing employer brand practices in IT sector. This leads to the variance verification for all 15 variables.

Table-4.3.2: Showing the Dimension of Factors influencing employer brand practices in IT sector

\begin{tabular}{|l|l|l|}
\hline Dimension of Factors influencing employer brand practices in IT sector & Initial & Extraction \\
\hline 1-Attract and retain best talent & 1.000 & .609 \\
\hline 2-Quality of customer service & 1.000 & .688 \\
\hline 3-Recognized icon & 1.000 & .492 \\
\hline 4-Employer of choice & 1.000 & .512 \\
\hline 5-Core corporate values & 1.000 & .505 \\
\hline 6-Leadership & 1.000 & .552 \\
\hline 7-Communication & 1.000 & .520 \\
\hline 8-Training and Counseling & 1.000 & .595 \\
\hline 9-Long term vision and mission & 1.000 & .726 \\
\hline 10-Nature of operations & 1.000 & .587 \\
\hline 11-Competition prevailing & 1.000 & .521 \\
\hline 12-Client restrictions and requirements & 1.000 & .496 \\
\hline 13-Market environment and business models prevailing & 1.000 & .497 \\
\hline 14-Flexibility in the budgets & 1.000 & .518 \\
\hline 15-Degree of CSR and Corporate governance practicing & 1.000 & .564 \\
\hline
\end{tabular}

Source: Primary data/ Structured Questionnaire

Extraction Method: Principal Component Analysis.

From the above table it is found that the 15 variables exhibit the variables from .492 to .726. This implies the range of variations defined between $49 \%$ to $72 \%$, this is adequate for factor segmentation from the variables. This leads to the factor formation as stated in the table below:

Table-4.3.3: Total Variance Explained the Dimension of Factors influencing employer brand practices in IT

\begin{tabular}{|c|c|c|c|c|c|c|c|c|c|}
\hline \multirow[t]{2}{*}{ Component } & \multicolumn{3}{|c|}{ Initial Eigen values } & \multicolumn{3}{|c|}{$\begin{array}{l}\text { Extraction Sums of } \\
\text { Squared Loadings }\end{array}$} & \multicolumn{3}{|c|}{$\begin{array}{l}\text { Rotation Sums of } \\
\text { Squared Loadings }\end{array}$} \\
\hline & Total & $\begin{array}{l}\% \text { of } \\
\text { Variance }\end{array}$ & $\begin{array}{l}\text { Cumu } \\
\%\end{array}$ & Total & $\begin{array}{l}\% \text { of } \\
\text { Variance }\end{array}$ & $\begin{array}{l}\text { Cumu } \\
\%\end{array}$ & Total & $\begin{array}{l}\% \text { of } \\
\text { Variance }\end{array}$ & $\begin{array}{l}\text { Cumu } \\
\%\end{array}$ \\
\hline 1 & 3.444 & 22.959 & 22.959 & 3.444 & 22.959 & 22.959 & 1.977 & 23.177 & 23.177 \\
\hline 2 & 1.526 & 10.171 & 33.129 & 1.526 & 10.171 & 33.129 & 1.908 & 12.720 & 35.897 \\
\hline 3 & 1.223 & 8.155 & 41.285 & 1.223 & 8.155 & 41.285 & 1.664 & 11.090 & 46.987 \\
\hline 4 & 1.153 & 7.688 & 48.973 & 1.153 & 7.688 & 48.973 & 1.573 & 10.486 & 57.473 \\
\hline 5 & 1.039 & 6.927 & 55.900 & 1.039 & 6.927 & 55.90 & 1.264 & 8.427 & 65.90 \\
\hline 6 & .955 & 6.364 & 62.264 & & & & & & \\
\hline 7 & .876 & 5.838 & 68.101 & & & & & & \\
\hline 8 & .800 & 5.330 & 73.431 & & & & & & \\
\hline 9 & .717 & 4.778 & 78.209 & & & & & & \\
\hline 10 & .672 & 4.477 & 82.687 & & & & & & \\
\hline 11 & .619 & 4.125 & 86.812 & & & & & & \\
\hline 12 & .575 & 3.835 & 90.647 & & & & & & \\
\hline 13 & .528 & 3.521 & 94.168 & & & & & & \\
\hline 14 & .470 & 3.132 & 97.300 & & & & & & \\
\hline 15 & .405 & 2.700 & 100.00 & & & & & & \\
\hline
\end{tabular}

Source: Primary data/ Structured Questionnaire

Extraction Method: Principal Component Analysis.

From the above table it is found that the 15 variables are reduced in to 5 predominant factors. It is also found that the 15 variables exhibit the total variance of $65.900 \%$. It is also ascertained that the 5 factors individually posses the variances $23.177 \%, 12.720 \%, 11.090 \%, 10.486$ and $8.427 \%$. This leads to the variable loadings for each factors of variables influencing employer brand practices in IT sector. The first factor consists of 4 variables, with the loading scores of $0.691,0.621,0592$ and 0.507 as strategic factor. The second factor consists of 4 variables with the score loadings of $0.689,0.680,0.663$, and 0.584 as Planning Factor. The third 
factor includes 3 variables with the score loadings of $0.788,0.643$ and 0.493 as quality factor, fourth factor consists of two variables with the score loadings of 0.739 and 0.638 as Operating factor and finally two variables with the score loadings of $0.799,0.514$ as Marker Factor influencing the adoption and inculcation of employer brand practices in IT sector.

Table-4.3.4: Rotated Component Matrix (a) along with the factor loadings and factors emerged

\begin{tabular}{|c|c|c|c|c|c|c|}
\hline \multirow{2}{*}{$\begin{array}{l}\text { Dimensions of Factors influencing employer brand } \\
\text { practices in IT sector }\end{array}$} & \multicolumn{5}{|c|}{ Component } & \\
\hline & 1 & 2 & 3 & 4 & 5 & \\
\hline 15- Degree of CSR and Corporate governance practicing & .691 & \multirow{4}{*}{\multicolumn{5}{|c|}{ Strategic Factors }} \\
\hline 14- Flexibility in the budgets & .627 & & & & & \\
\hline 5- Core corporate values & .592 & & & & & \\
\hline 4-Employer of choice & .507 & & & & & \\
\hline 7- Communication & .150 & .689 & \multirow{4}{*}{\multicolumn{4}{|c|}{ Planning Factors }} \\
\hline 1-Attract and retain best talent & -.217 & .680 & & & & \\
\hline 11-Competition prevailing & .081 & .663 & & & & \\
\hline 3-Recognised icon & .265 & .584 & & & & \\
\hline 2- Quality of customer service & .019 & .116 & .788 & \multirow{3}{*}{\multicolumn{3}{|c|}{ Quality Factors }} \\
\hline 8- Training and Counseling & 246 & .148 & .643 & & & \\
\hline 12- Client restrictions and requirements & .465 & .133 & .493 & & & \\
\hline 10- Nature of operations & .093 & .136 & .115 & .739 & \multirow{2}{*}{\multicolumn{2}{|c|}{$\begin{array}{l}\text { Operating } \\
\text { Factors }\end{array}$}} \\
\hline 6- Leadership & -.034 & -.066 & .150 & .685 & & \\
\hline 9-Long term vision and mission & .255 & .112 & -.077 & .071 & .799 & Market \\
\hline 13- Market environment and business models prevailing & -.009 & .272 & .265 & .297 & .514 & Factors \\
\hline
\end{tabular}

Extraction Method: Principal Component Analysis. Rotation Method: Varimax with Kaiser Normalization a Rotation converged in 13 iterations.

Source: Primary data/ Structured Questionnaire

\section{Factor Analysis-II:Benefits of Employer Brand Practices}

The benefits of employer brand practices to the organization and employees in IT sector is consist of 15 variables therefore the data reduction is done through the application of factor analysis by principal component method and the following results are obtained.

Table-4.3.5: Communalities

\begin{tabular}{|l|l|l|}
\hline Benefits of employer brand practices & Initial & Extraction \\
\hline 1-Corporate identity- stronger public image & 1.000 & .916 \\
\hline 2-Attractiveness to outsiders-increased customer confidence & 1.000 & $\mathbf{. 9 5 1}$ \\
\hline 3-Quality and number of potential recruits-increased employee loyalty & 1.000 & .945 \\
\hline 4-Insider identification-improved employee morale & 1.000 & .945 \\
\hline 5-Organizational Performance & 1.000 & .922 \\
\hline $\begin{array}{l}\text { 6-Increased employee retention- Employer Value Proposition (EVP)- Proud to } \\
\text { work with and confidence of organization cares about my career development. }\end{array}$ & 1.000 & .891 \\
\hline 7-Competitive advantage & 1.000 & $\mathbf{. 8 0 6}$ \\
\hline 8-Increased workforce productivity and profitability & 1.000 & .863 \\
\hline 9-Increased recruitment of top employees & 1.000 & .935 \\
\hline 10-Positive financial bottom line & 1.000 & .902 \\
\hline 11-Lower recruitment costs & 1.000 & .938 \\
\hline 12-Minimized loss of talented employees & 1.000 & .924 \\
\hline 13-Maintenance of core competencies & 1.000 & .882 \\
\hline 14-Increased level of organizational commitment among the employees & 1.000 & .842 \\
\hline 15-Improved employee relationships & 1.000 & .848 \\
\hline
\end{tabular}

Extraction Method: Principal Component Analysis.

Source: Primary data/ Structured Questionnaire

From the Table 4.3.5, it is found that the 15 variables exhibit the variation from .806 to .951 . This implies the range of variations defined "between" 80 percent to 95 percent, this is adequate for factor segmentation from the variables. This leads to the factor formation as stated in the table below:

Table 4.3.6: Total Variance Explained

\begin{tabular}{|c|c|c|c|c|c|c|c|c|c|}
\hline \multirow[t]{2}{*}{ Component } & \multicolumn{3}{|c|}{ Initial Eigen values } & \multicolumn{3}{|c|}{ Extraction Sums of Squared Loadings } & \multicolumn{3}{|c|}{ Rotation Sums of Squared Loadings } \\
\hline & Total & $\begin{array}{l}\% \text { of } \\
\text { Variance }\end{array}$ & $\begin{array}{l}\text { Cumulat } \\
\text { ive } \%\end{array}$ & Total & $\begin{array}{l}\% \text { of } \\
\text { Variance }\end{array}$ & Cumulative $\%$ & Total & $\begin{array}{l}\% \text { of } \\
\text { Variance }\end{array}$ & Cumulative $\%$ \\
\hline 1 & 9.331 & 62.203 & 62.203 & 9.331 & 62.203 & 62.203 & 6.872 & 45.810 & 45.810 \\
\hline 3 & 1.621 & 10.808 & 90.054 & 1.621 & 10.808 & 90.054 & 3.128 & 20.856 & 90.054 \\
\hline 4 & .493 & 3.289 & 93.343 & & & & & & \\
\hline
\end{tabular}


Compensation And The Corporate Employee Benefits: Exploring The Dimensions of Employer.....

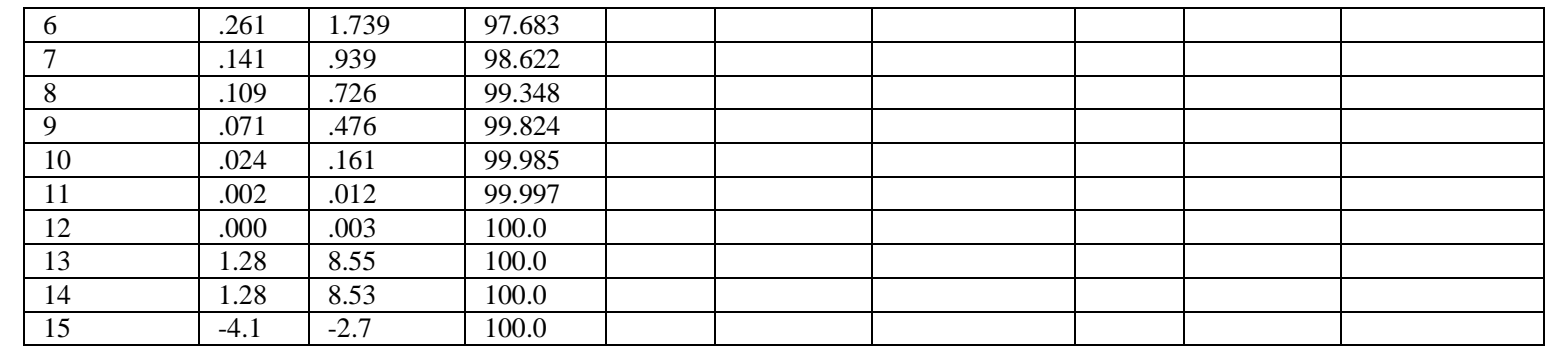

Extraction Method: Principal Component Analysis.

Source: Primary data/ Structured Questionnaire

Table-4.3.7: Rotated Component Matrix(a)

\begin{tabular}{|c|c|c|c|}
\hline \multirow[t]{2}{*}{ Benefits of employer brand practices } & \multicolumn{3}{|c|}{ Component } \\
\hline & 1 & 2 & 3 \\
\hline 2- Attractiveness to outsiders-increased customer confidence & .952 & \multirow{8}{*}{\multicolumn{2}{|c|}{ Stability Factor }} \\
\hline 11- Lower recruitment costs & .937 & & \\
\hline 5- Organizational Performance & .927 & & \\
\hline 3- Quality and number of potential recruits-increased employee loyalty & .871 & & \\
\hline 13- Maintenance of core competencies & .842 & & \\
\hline 9- Increased recruitment of top employees & .834 & & \\
\hline 10- Positive financial bottom line & .802 & & \\
\hline 12- Minimized loss of talented employees & .760 & & \\
\hline 1- Corporate identity- stronger public image & .930 & \multirow{4}{*}{\multicolumn{2}{|c|}{ Brand Image Factor }} \\
\hline $\begin{array}{l}\text { 6- Increased employee retention- Employer Value Proposition (EVP)- Proud to work } \\
\text { with and confidence of organization cares about my career development. }\end{array}$ & .851 & & \\
\hline 4- Insider identification-improved employee morale & .756 & & \\
\hline 8- Increased workforce productivity and profitability & .669 & & \\
\hline 15- Improved employee relationships & \multirow{3}{*}{\multicolumn{2}{|c|}{ Loyalty Factor }} & .916 \\
\hline 7- Competitive advantage & & & .894 \\
\hline 14- Increased level of organizational commitment among the employees & & & .728 \\
\hline
\end{tabular}

Extraction Method: Principal Component Analysis. Rotation Method: Varimax with Kaiser Normalization. A Rotation converged in 6 iterations.

Source: Primary data/ Structured Questionnaire

On the basis of the principal component analysis with Varimax rotation using Kaiser Normalization, The benefits of employer brand practices to the organization and employees in IT sector variables are grouped into three factors. The factors are titled on the basis of the nature and the factor loadings scores.

Factor-I: Stability Factor: This factor is loaded with eight variables and all the variables are having the common feature of stability of business, resources and cost. The variables loaded under this factor are Attractiveness to outsiders-increased customer confidence with the factor loading score of .952; Lower recruitment costs with the factor loading score of .937; Organizational Performance with the factor loading score of .927; Quality and number of potential recruits-increased employee loyalty with the factor loading score of .871; Maintenance of core competencies with the factor loading score of .842; Increased recruitment of top employees with the factor loading score of .834 ; Positive financial bottom line with the factor loading score of .802; Minimized loss of talented employees with the factor loading score of .760 .

Factor-II: Image Factor: This factor is loaded with four variables relating to the image of the company and the employees working in the firm. It is represented with increased level of revenues and reduced employee turnover. The variables loaded in this factor are Corporate identity- stronger public image with the factor loading score of .930; Increased employee retention- Employer Value Proposition (EVP)- Proud to work with and confidence of organization cares about my career development with the factor loading score of .851; Insider identification-improved employee morale with the factor loading score of .756 and Increased workforce productivity and profitability with the factor loading score of .669.

Factor-III: Loyalty Factor: The third factor is tiled as Loyalty Factor. This factor is loaded with three variables namely improved employee relationships with the factor scoring load of 0.916 , competitive advantage with the factor loading score of 0.894 and Increased level of organizational commitment among the employees with the factor loading score of 0.728 respectively 


\section{Findings And Suggestions}

1. IBM follows international standard of compensation and benefits is expressed by 39.20 percent of the employees as against to 20.80 percent in hexaware. IT is followed by 30.80 percent of the employees in IBM feels that, the compensation is at on par with the industry standard and 22 percent of them feel that, the compensation system is custom designed one. In case of hexaware, the compensation system is designed and adopted on the basis of custom designed standard, is expressed by 58 percent of the employees in the sample. Only 20.80 percent is agreed the compensation and benefits are paid as on par with the international standard. Hence, there is a long way to fix the uniform standard in compensation and benefits in both the companies. When comparing both the companies in the sample, it is IBM is better when compared to hexaware.

2. Rewards and recognition related aspects at work is perceived by the employees of IMB are as follows. The employees of IMB feels the rewards given to them are conservative and not comparable by 36 percent, fair and attractive by 29.20 percent and best in class and above the range by 34.80 percent in the sample. On the other hand, it is observed that, 39.60 percent of the employees from hexaware feels that, the rewards given are conservative and not comparable, 38 percent feels that fair and attractive and 22.40 percent views as best in class and above the range. It indicates that IBM is good in reward and recognition of the employees at work for their services. Rewards and recognition is more important to improve the morale of the employees at work place. Rewards can help the employees to grow in career and to have good level of loyalty towards the company.

3. The prime variables influencing the compensation and benefits as employer brand practices in IT sector are unanimously agreed by the respondents from both IBM and hexaware with high level of mean values. The primary variables are identified with the higher mean score of above 4.30.The prime variables influencing employer brand image in IT sector are fair and industry standard pay package and remuneration for additional work.

4. reward and recognition as a factor in employer brand building is observed in the order of priority are Rewards for the professional excellence with the mean value of 3.14 and 3.04, Recognition of talents and encouraging with the mean value of 3.12 and 3.02, Supportive for creativity and innovations with the mean value of 3.09 and 2.96, Research and development opportunities at work with the mean value of 3.08 and 2.95 and Patenting and ownership of knowledge with the mean value of 3.06 and 2.85 in IBM and Hexaware respectively.

5. Benefits of employer brand practices in IT sector are classified on the basis of mean value. The variables scored high level of mean score of above 3.5 are considered as prime benefits and the variables recorded less than 3.5 mean score are considered as moderately benefited dimensions in the IT sector. The prime benefit dimensions of employer branding are increased level of Corporate identity- stronger public image with the mean score of 3.55, Quality and number of potential recruits-increased employee loyalty with the mean score of 3.53 , increased level of competitive advantage with the mean value of 3.55 , Increased recruitment of top employees with the mean score of 3.52; Positive financial bottom line with the mean score of 3.53 and Lower recruitment costs 3.55 in the sample survey of the companies in the sample. This indicates that the benefits of employer brand for the present and future purposes of the company. Hence, employer banding is indispensable to the companies in the IT sector.

6. Since $\mathrm{p}$ value is less than 0.01 , the null hypothesis, There is no significant difference between the perceptions of the employees in the sample with regard to Compensation as a factor in the employer brand development practice in IT sector is rejected at $1 \%$ level of significance.

7. Since $\mathrm{p}$ value is less than 0.01 , the null hypothesis, There is no significant difference between the perceptions of the employees in the sample with regard to Compensation as a factor in the employer brand development practice in IT sector is rejected at $1 \%$ level of significance. Hence, it is concluded that, there is a highly significant difference between the perceptions of the employees in the sample with regard to Compensation as a factor in the employer brand development practice in IT sector. Based on the mean value, it is noted that, health, safety and welfare measures and financial protection to self and family are the two major variables act as a prime in compensation factor of employer brand practice in It sector. Hence, the It firms in the sample need to focus on these dimensions while framing the compensation policy of a company in order to have a competitive and contemporary compensation policy as a employer brand practice in the market place and to attract the clients and potential employees towards the company.

8. Since $\mathrm{p}$ value is less than 0.05 , the null hypothesis, There is no significant difference between the perceptions of the employees in the sample with regard to rewards and recognition as a factor in the employer brand development practice in IT sector is rejected at 5\% level of significance. Hence, it is concluded that, there is a significant difference between the perceptions of the employees in the sample with regard to rewards and recognition as a factor in the employer brand development practice in IT sector. Based on the mean ranks, it is noted that, patenting and ownership of knowledge and recognition of talents 
and encouraging are the two important variables in the reward and recognition factor of employer brand management in the sample firms in IT sector. Hence, rewards and recognition of young talents play a role in employer brand building in the IT sector.

\section{1: Summary and Conclusion}

Employer branding is the response of Human Resources Management to the particular market circumstances. Very important factor in achieving employer branding objectives is to have a clearly defined employer brand strategy. Regarding the career seekers in the field of engineering, potential hires find companies that are innovative, produce exciting products and offer exciting services. The study results clearly indicate the role of personal and demographic variables influence, organizational factors influence in the employer brand practices to a greater extent. Similarly, the impact of employer brand practices on the attrition and retention of the employees is highly significant indicating the higher levels of impact. Hence, employer brand practices have definite impact on the turnover and performance of the employees in IT firms.

\section{2: Limitation and Further Scope of the Research}

Since the study is conducted with the selected firms in Chennai city, the impact of socio cultural basics need to be considered while adopting the suggestions to other geographical locations. The firms in the sample are heterogeneous, if a study conducted among the homogeneous group could have been a solid source to estimate the impact on a specific group. The sample is selected on convenient basis and the size is limited. In general behavioural studies adopt large sample size for normalization of results and to improve the reliability.

The study is restricted its scope with private and shop and establishments operating in Chennai city. Multi city and multinational sample collection could have been a wide scope for the assessing the impact. The present study is micro in nature and focused approach is followed. The further studies may be conducted with broader sample and scope of the study variables.

[1] Aiesec.Employer branding program. [online]. 2010. [cit. 2010-09-22].

http://www.aiesec.org/cms/aiesec/ai/central\%20and\%20eastern\%20europe/slovaKia/aiesec\%20nitra/pre_firmy/xemployer_brandin gx_program.

[2] Ambler, T. \& Barrow, S. (1996). The employer brand. Journal of Brand Management, 4 (3), 185-206.

[3] Armstrong, Michael. A Handbook of Human Resource Management Practice. Kogan Page Limited, 1999.

[4] Backhaus K. \&Tikoo S. (2004). Conceptualizing and researching employer branding. Career Development International, 9 (4), 501-517.

[5] Balmer, J.M.T. (2001), "The Three Virtues and Seven Deadly Sins of Corporate Brand Management", Journal of General Management, Volume 27, No.1, pp. 1-17.

[6] Barrow, s. And mosley, r. The employer brand: bringing the best of brand management to people at work. Chichester: john wiley\& sons: 2005. 207 p. Isbn 978-0-470-01273-4.

[7] Burstiner, Irving. The Small Business Handbook. Prentice Hall, 1988

[8] Chaminade B (2007). A retention checklist: how do you rate? www.humanresourcesmagazine.co.au. Accessed, 28 November, 2007.

[9] Emloyer brand international. The world's most attractive employers 2010.

[10] Green, Paul C. Building Robust Competencies: Linking Human Resource Systems to Organizational Strategies. Jossey-Bass, 1999.

[11] Gubman, Edward L. "The Gauntlet is Down." Journal of Business Strategy. November-December 1996.

[12] Harris, k. Developing and managing a successful employer brand. In hr summit 2010. Perth. 2010. [cit. 2010-09-25].

[13] Johnston, John. "Time to Rebuild Human Resources." Business Quarterly. Winter 1996.

[14] Litheko E (2008). Training them young is the way to up the skills base. Sunday/Business Times, 29 June, p. 26

[15] Minchington, B (2010) Employer Brand Leadership - A Global Perspective, Collective Learning Australia.

[16] Mosley, Richard W., 2007. Customer Experience, Organisational Culture and the Employer Brand. Brand Management, Nov 2007, Vol. 15, No. 2, pp. 123-134.

[17] Radford, t. 7 ways to sell your employer brand [online]. 2009. [cit. 2010-09-25].

[18] Reece, Barry L., and Rhonda Brandt. Effective Human Relations in Organizations. Boston: Houghton Mifflin, 1993.

[19] Roberts, Gary, Gary Seldon, and Carlotta Roberts. Human Resources Management. Washington, D.C.: Small Business Administration, n.a.

[20] Rossiter, Jill A. Human Resources: Mastering Your Small Business. Upstart Publishing, 1996.

[21] Schneider, B. (1987). The people make the place. Personnel Psychology, 40, 437-54.

[22] Solomon, Charlene Marmer. "Working Smarter: How HR Can Help." Personnel Journal. June 1993.

[23] Ulrich, Dave. Delivering Results: A New Mandate for HR Professionals. Harvard Business School Press, 1998. 